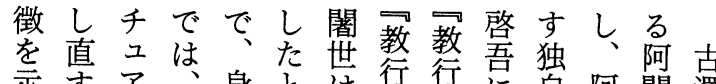
示守ア、身とは行行に自阿闇澤 すこルこ体お証証よの闑世平 となの的りピ文齐る理世は作 に苦 コ・゙リ類類阿論㕦、 よし教社あチ海モンフよ つみ行会るュにに世デプロる てを証的。ア登は品ルレイて

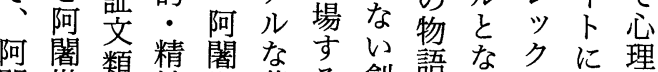
闇世類神世苦る創語なっスな理 世自に的はし阿作はたとる的 の身描にスみ闇の涅。い土観 スの描もピを世部粩しうデ点 ピ訴苦り抱を分䅅加日妿

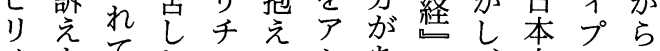
チをてむュてセあっ人呈 ב中い上アい石観古的コ舎 ア心るうルたメ。経澤母ン城 ルに阿になこン古些济年プの 苦系世つしはすが観らのッ劇 し列のたみ拙る元経に心クに みにス。が稿令とに帖小性ス登 の整ピ本原でくし阽此をに場 特理り稿因示阿た疏条表対䋕 希理父は

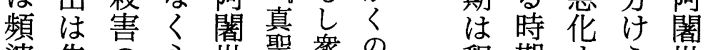
婆告の心世聖衆ご釈期すら世 梁白後では全生ご尊:るれの

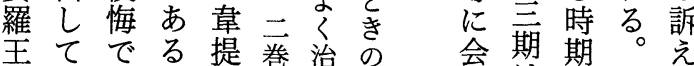

王で点提券治品会期期。充

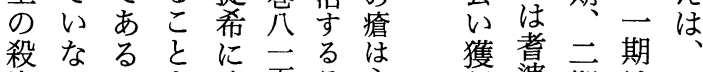

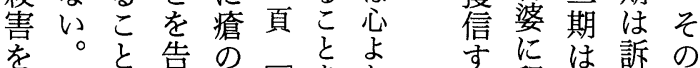

ル

な

苦

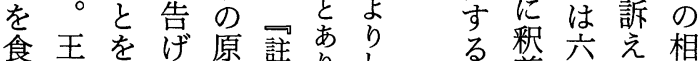

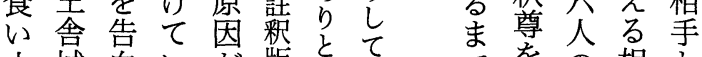

止城白い加怔岳生

めのしる身壮

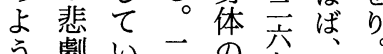

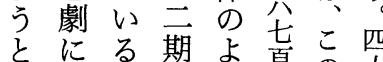

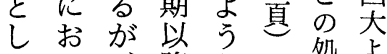

た心降な努名

たて袁で物要起

め母提は質氞

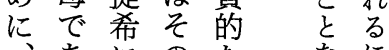

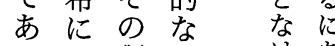

阿等致理电

䦔韋它由品

世提のをで

讨南

で弆の相と

で勧大擘呙

あ市臨容

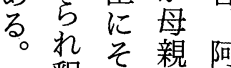

ま整杂慗荫

尊尊望韋世

未

、毞执提

宸崖師幕状

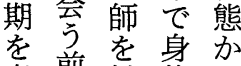

打

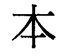

来

考等勧体 察でめら瘡期 


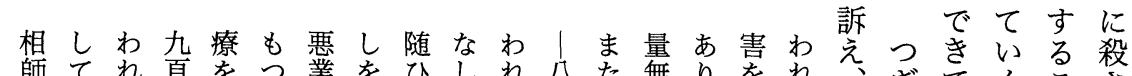

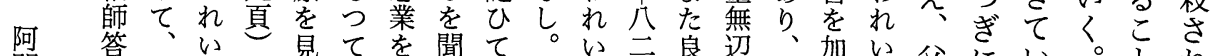

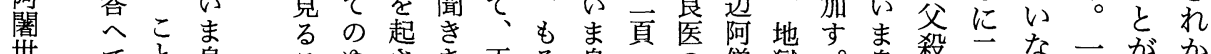

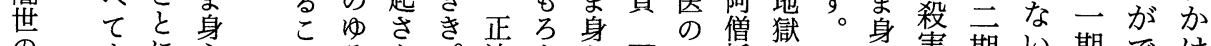
の まに心急ん。。法も灾司わ祗をわ忍害期い期でけ

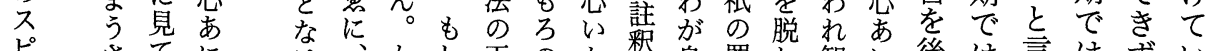

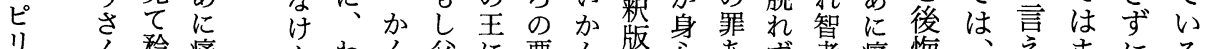

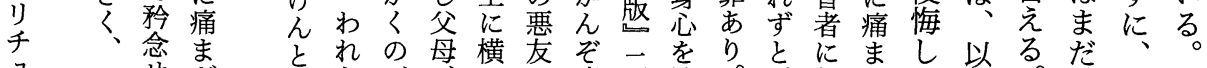

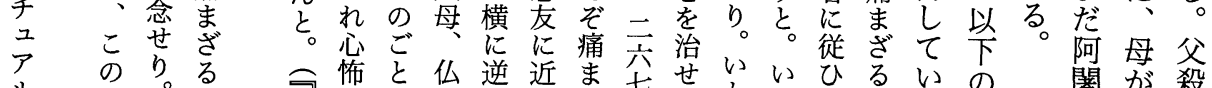

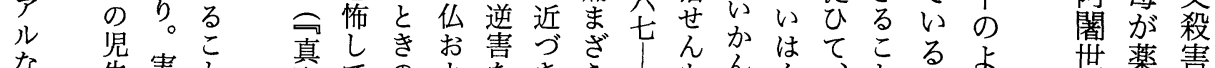

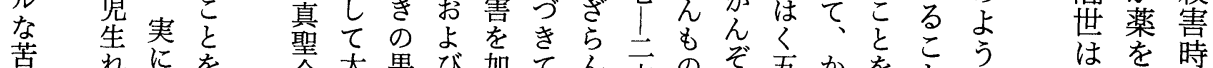

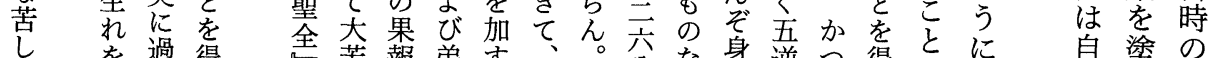

孔を過得至苦報弟す。分な身逆つ得をに塗の

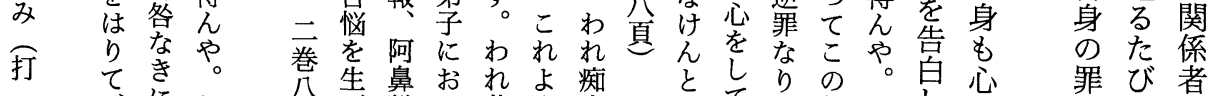

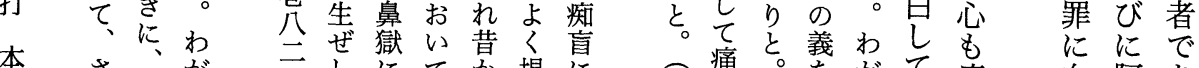

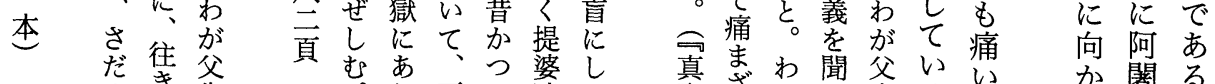

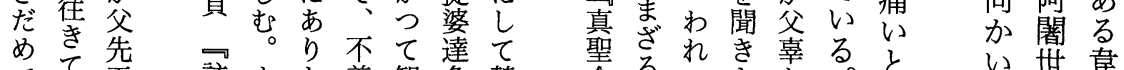

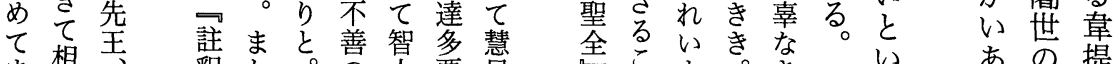

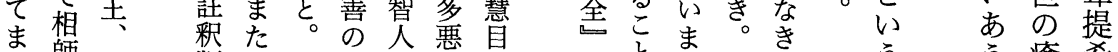

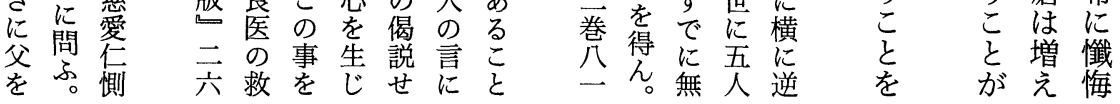

いの、思罪しる。悪父の

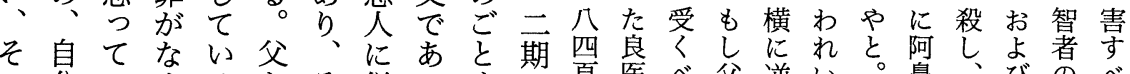
の分いくるとそ従つく筫医べ父逆い。鼻、びのべ 罪だる、と自れつた正告沉しを害ま言地お比、し かけ。智い分をたこし白註が。害を身真獄よ岳かと。

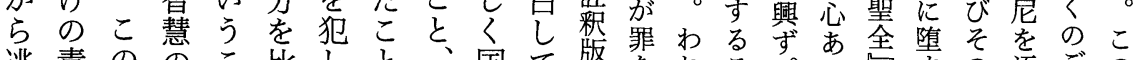
逃責ののこ比しと、国て版を㕲こす。全等 の污ごの れ任時なとべた二元いる救いとわ痛云べ父し、語 らで点いがる者三つ統る療まあれみ巻しをを六をを れはで自わこはうに治父元守久れまな殺僧言聞 るなは分かと永に自し殺|るしばたき言。さ祇言く

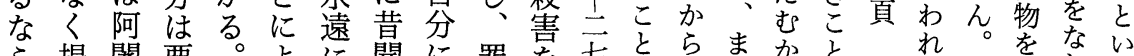

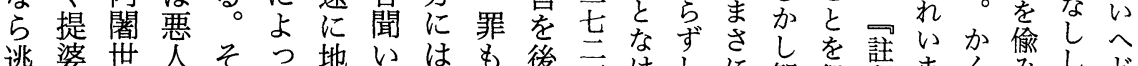

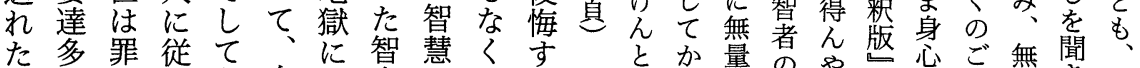

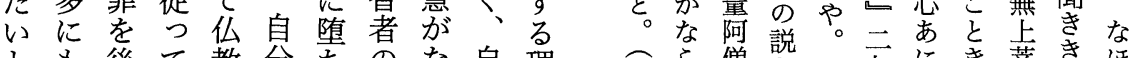

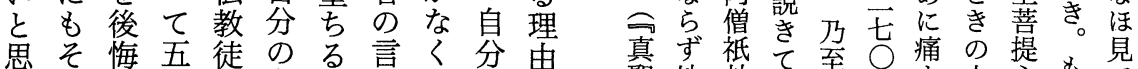
思そ悔五徒 のる言く分冎真ず祇て地至 ○痛の提も見

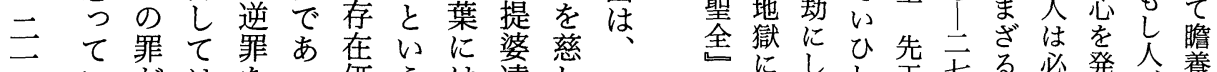

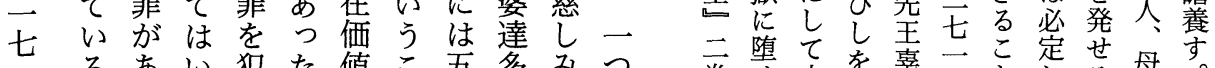

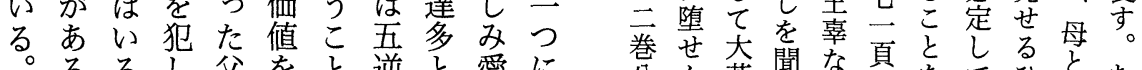

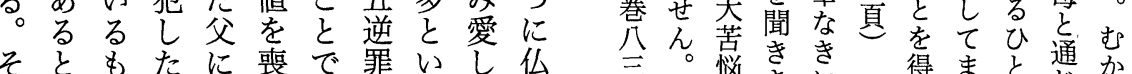

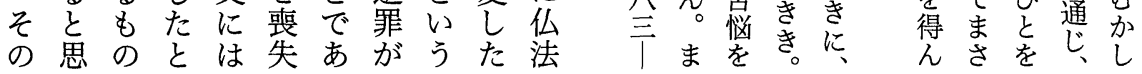




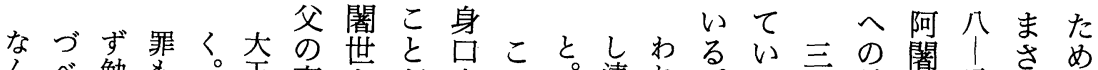

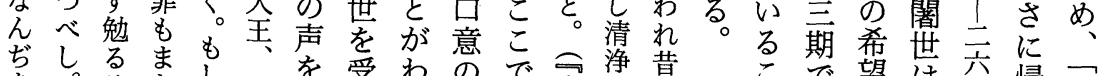

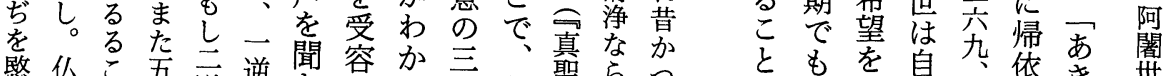

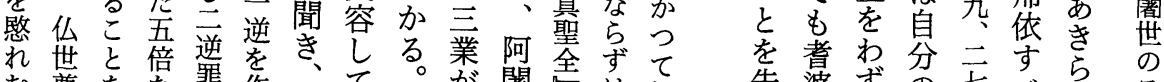

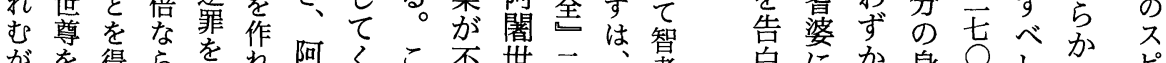

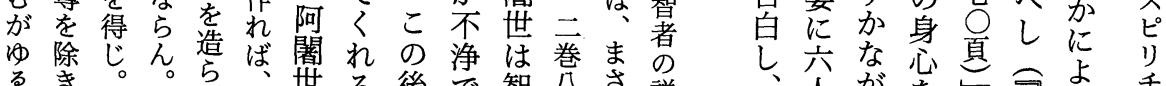

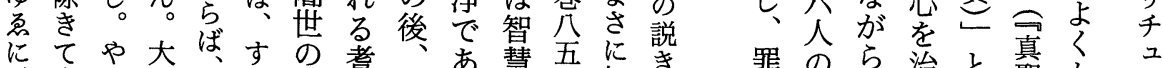

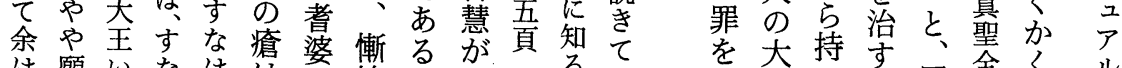

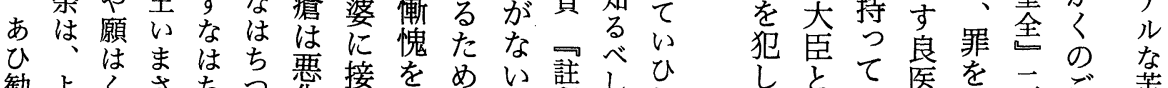

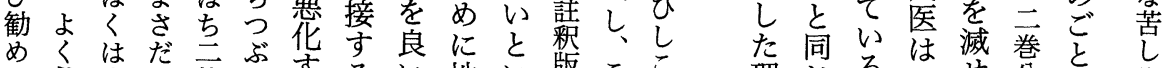

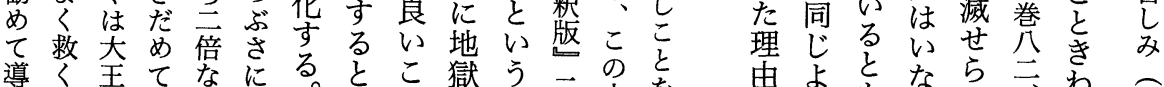

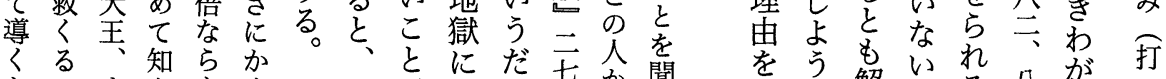

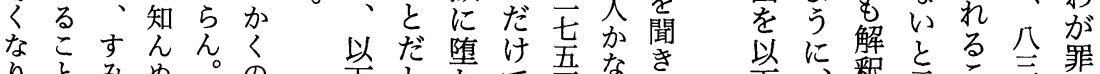

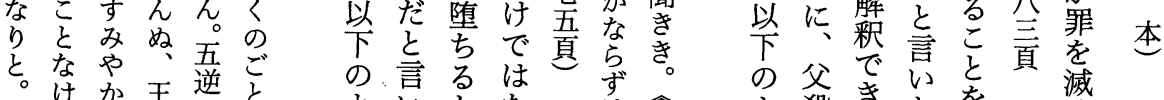

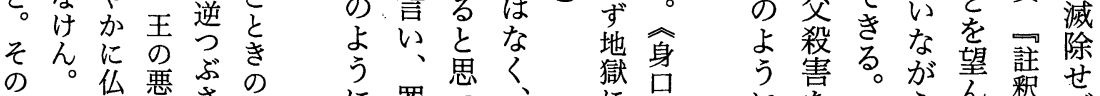

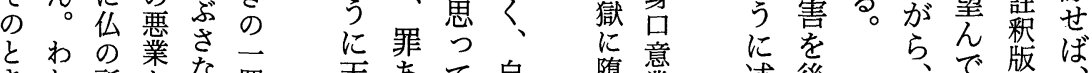

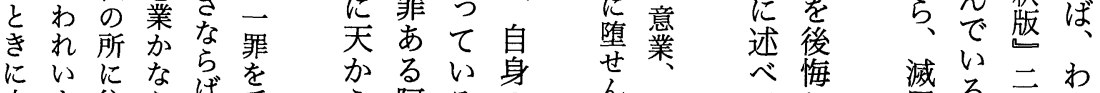

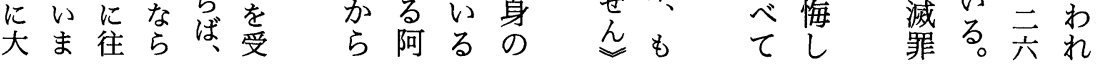

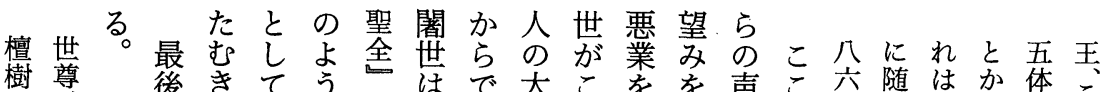
樹尊後きてう住で大こをを声こ六随はか体こ

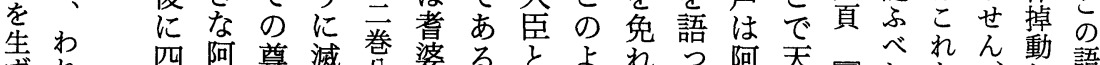

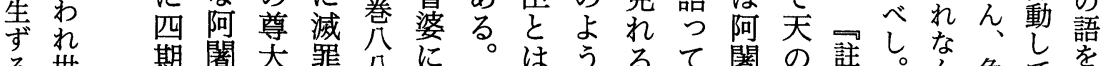

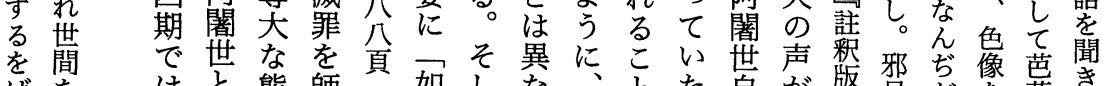
ばをはと態師帤しな如なとた自が版冴がを蕉き 見見 釈な度へ註莱て、る自は阿身聞省交父現樹 は

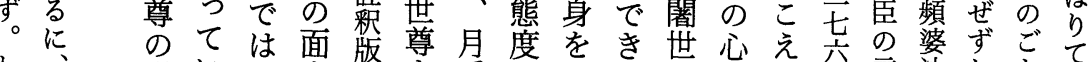

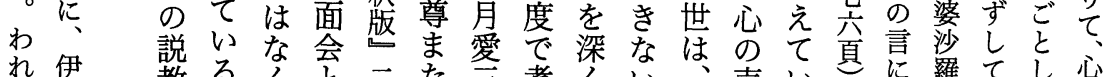

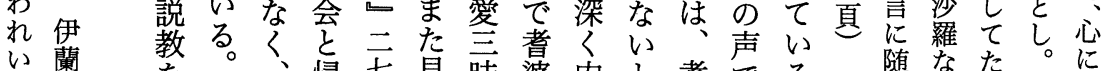
い子蘭を㷌七見昧婆内と耆でる随なた。に

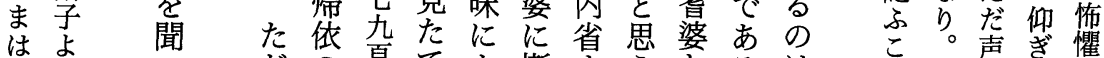

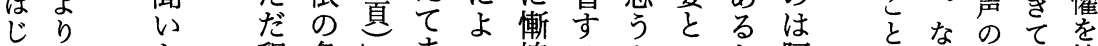
め伊た釈条しまう愧るなのうと阿ななんみ答懐 て蘭 後尊件とつてすこう会解闍学ぢあへけ 伊樹にに聞ら身るとに話喽世的いるてり。

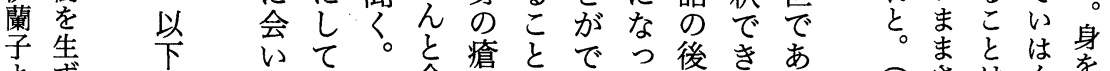

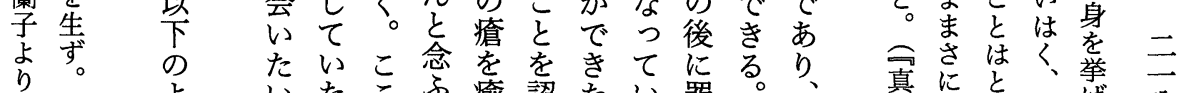

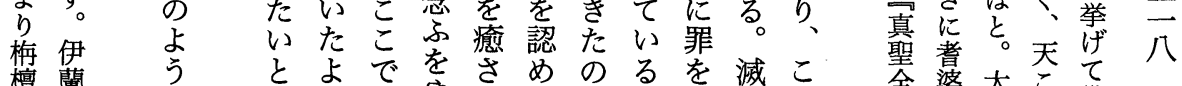

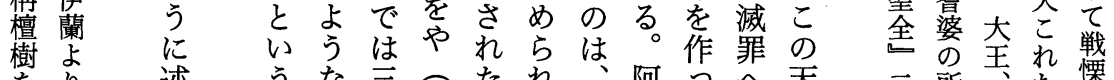

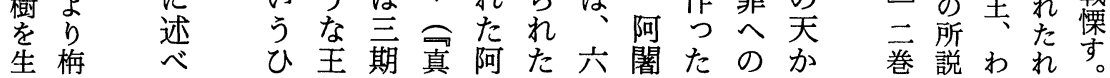




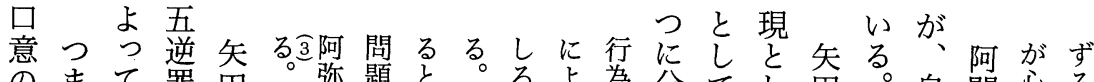
阿 の

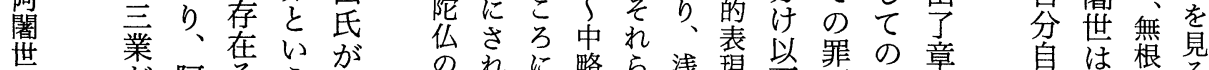

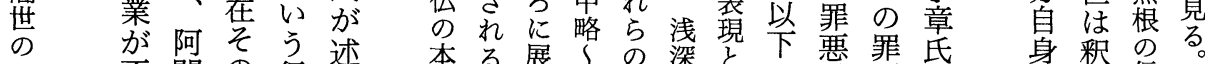
不闍の行述本る展 本罪深と悪罪氏 身釈のる。

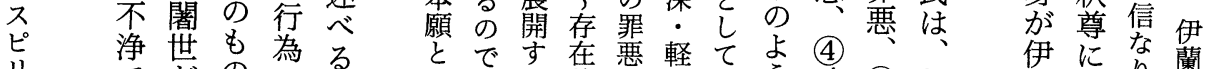

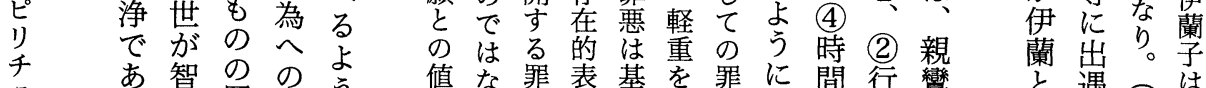

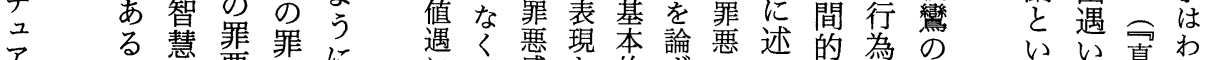

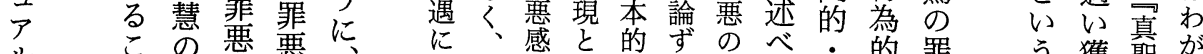

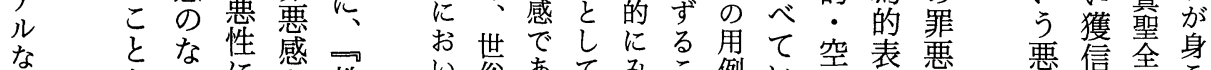

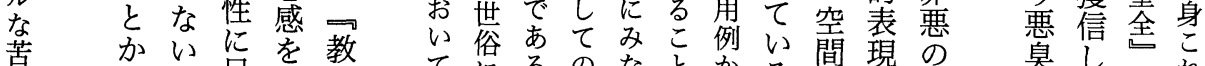

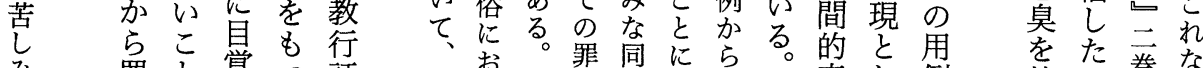
み罪と覚っ証罪い人悪算にら表し例放こ巻な

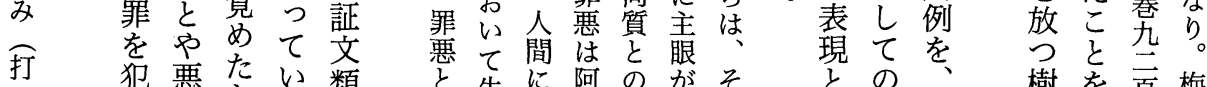

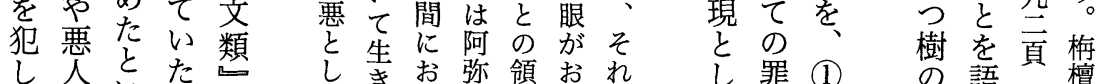

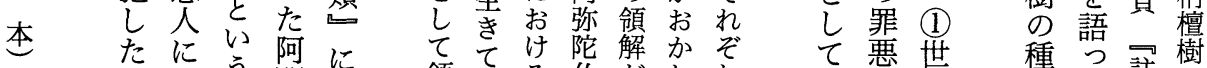
た に

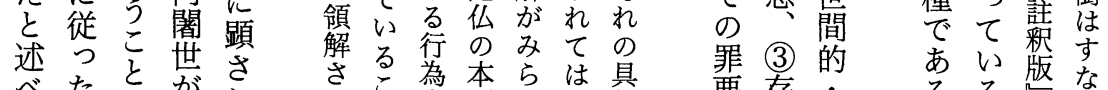

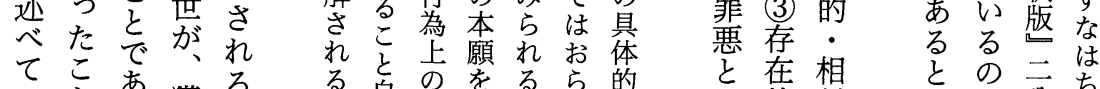

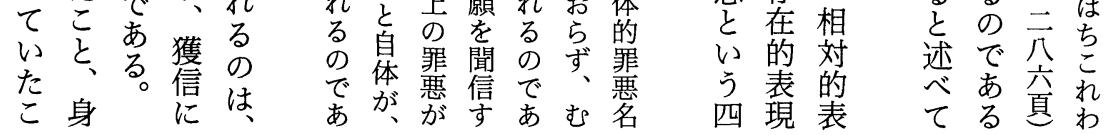

えれ態そピがく意きたこ釈 るる度のリでれ味合スと尊阿 よ。で人チをををうピがの闍 う答苦がュた人作必りで存世 にえし苦アののり要チき在は 側をむしルで存出がュたにス に与人みなあ在しあア。よ゚ いえのに苦るがたつル阿つリ るる傍向し。あのたな闇て、チ ここらきみこつは。苦世いュ ととに合をのて阿そしがそア ででいえも阿は闍のみ父のル あはるるつ闍じ世苦を殺苦な りなとよ人世め自し 乗害し苦 、くいう、ののて身みりををみし そ、う、ケ物そでを越後のみ のそこそア語のあ乗え悔元を 意のとのを苦るりるすすを受 味人で人息号しが越にるな容

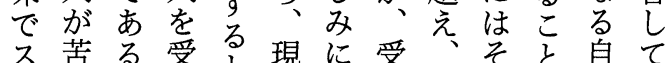
二 ス苦る受を現に受新它に自て

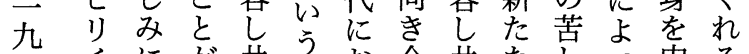
チにが共うお合共なしう内る 工向示感という感生みて省者 アき唆すとてこしきにも守婆 ル合さる梳とてる向つると

地来とにうはと 獄と五存、は、 結 の出桇逆罪そと伊 恐遇ととのも蘭 怖いのいを をは出うのそ譬 乗 時遇悪がので り間い臭伊種は 越的に蘭が伊 え・よ目とあ蘭 る空つにいるの こ間て見うか臭 々的領え悪 らい がに解る臭でで でもでそをああ き広き导放る。 のるの為樹も臭 でたでがのとい あめあ現種もが る。るれれで悪 阿そとなう阿臭 闍しいた世 あ 世てうたとる は如こめいの 


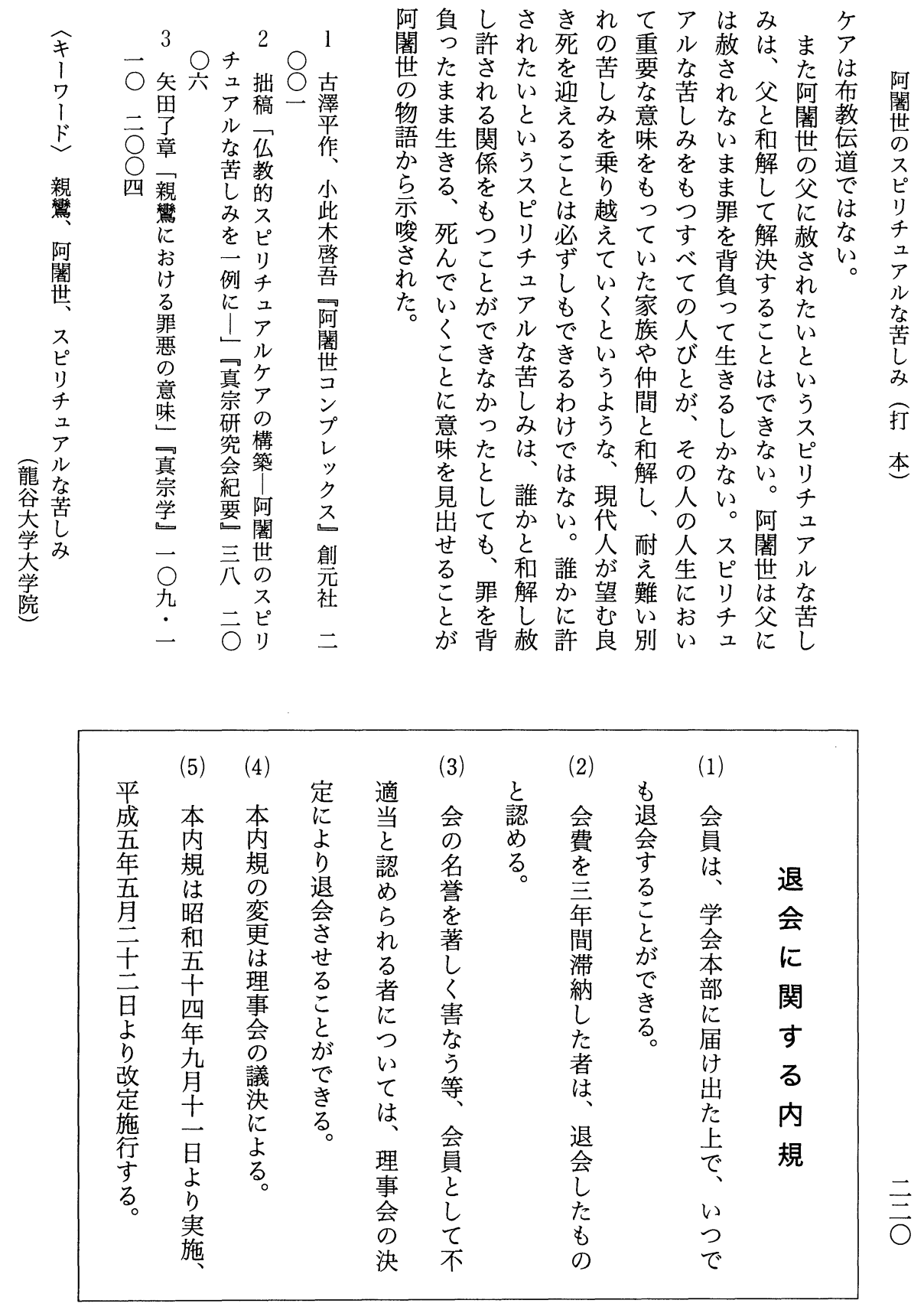




\section{Zonkaku's guilt}

TAKASE Daisen

How, according to Shinran and Zonkaku, do we recognize sin? For Shinran, sin is first made known by Amida Buddha. For Zonkaku, sin is something of which beings become self-aware. Amida Buddha's grace transcends one's self-awareness of sin. We should directly experience truth through religious experience, not intellectually like Shinran.

\section{Saigin's Fraternal Quarrel}

FuJITA Shinshō

The central issue in the fraternal quarrel of the Jōo period (1652-1655) is whether Saigin's thought deviated toward solipsism. At present this problem has not been sufficiently explored. Here I would like to examine the controversy on the basis of a document Saigin appears to have written earlier, namely the Fumonbonsho. There are insufficent materials upon which to base a comparison with Saigin's later thought, but it does seem that the quarrel had a serious impact. For this reason, the Fumonbonsho is an important source, and valuable for the development of Shinshū doctrine.

\section{The Spiritual Pain of Ajātaśatru}

Uснімото Mikuru

Ajātaśatru who appears in the Kyōgyōsyō monrui has a spiritual pain. Ajātaśatru was able to overcome his spiritual pain thanks to Jiva and the Buddha's assistance and empathy.

Spiritual caring does not have the mission of giving a answer, but rather helping a person to be able to face suffering.

Modern people consider a good death to involve reconciliation with someone. However, to live and die bearing one's sin without reconciliation also has meaning. 